\title{
ANALISIS PENERAPAN BENTUK-BENTUK TINDAK PIDANA PEMILU
}

\author{
Oleh : DUDUNG MULYADI *)
}

(dudungmulyadi dfh@yahoo.com )

\begin{abstract}
Criminal Election can be included in special crimes, namely election crimes and violations, both regulated in the Criminal Code (KUHP) and regulated in the Law of the Republic of Indonesia Number 7 of 2017 concerning General Elections. The parties that can be countered against election actions are: a) Election Organizers (KPU, Bawas/u, Government); b) General Election Participants (Political Parties, Candidates for DPR, DPD, DPRD, Candidates for President and Vice President); c) Society as a legal subject (as a voter, the Success Team includes the People who invite not to use their voting rights).
\end{abstract}

Keywords: Election Crimes, Forms of Election Crimes

\begin{abstract}
Abstrak
Tindak Pidana Pemilu dapat dimasukkan dalam pidana khusus yaitu pidana pemilu dan pelanggaran baik diatur dalam Kitab Undang-Undang Hukum Pidana (KUHP) dan diatur dalam Undang-Undang Republik Indonesia Nomor 7 Tahun 2017 tentang Pemilihan Umum. Adapun para pihak yang dapat disangkakan terhadap tindak pemilu adalah: a) Penyelengara Pemilu (KPU, Bawaslu, Pemerintah); b) Peserta Pemilihan Umum (Partai Politik, Calon DPR, DPD, DPRD, Calon Presiden dan Wakil Presiden); c) Masyarakat sebagai subjek hukum (sebagai pemilih, Tim Sukses termasuk Masyarakat yang mengajak tidak menggunakan hak suaranya).
\end{abstract}

Kata Kunci: Tindak Pidana Pemilu, Bentuk-Bentuk Tindak Pidana Pemilu

\section{PENDAHULUAN}

Salah satu persyaratan pelaksanaan sistem demokrasi adalah keikutsertaan rakyat dalam proses pemerintahan. Masyarakat mempunyai akses ke dalam sistem pemerintahan dengan memberikan partisipasi dalam memilih siapa yang akan menjadi pemimpin mereka. Dalam sistem negara dimana terbentuk Lembaga Perwakilan Rakyat, maka kemauan rakyat itu diwakilkan kepada mereka yang duduk dalam lembaga perwakilan rakyat.

Pemilihan umum (selanjutnya disingkat Pemilu) secara langsung oleh rakyat merupakan sarana perwujudan kedaulatan rakyat guna menghasilkan pemerintahan negara yang demokratis berdasarkan Pancasila dan Undang-Undang Dasar Negara

\footnotetext{
*) Dosen Tetap Fakultas Hukum Universitas Galuh
} 
Republik Indonesia Tahun 1945 (selanjutnya disingkat UUD 1945). Pasal 1 ayat (2) UUD 1945 menyatakan bahwa "kedaulatan berada di tangan rakyat dan dilaksanakan menurut Undang-Undang Dasar". Penyelenggaraan pemilihan umum secara langsung, umum, bebas, rahasia, jujur dan adil dapat terwujud apabila dilaksanakan oleh penyelenggara pemilihan umum yang mempunyai integritas, profesionalisme dan akuntabilitas.

Akuntabiltas berarti setiap pihak yang terlibat dalam penyelenggaraan Pemilu harus mempertanggungjawabkan pelaksanaan tugas dan kewenangannya kepada publik baik secara politik maupun secara hukum. Bertanggung jawab secara politik berarti setiap unsur yang terlibat dalam penyelenggaraan Pemilu mempunyai kewajiban menjelaskan kepada masyarakat fungsinya dan alasan tindakan yang diambil. Bertanggungjawab secara hukum berarti setiap pihak yang diduga melakukan pelanggaran hukum perihal asas-asas Pemilu yang demokratik wajib tunduk pada proses penegakan hukum berdasarkan asas praduga tak bersalah dan asas due process of law yang diatur dalam KUHAP. Oleh karena itu salah satu prasyarat penting dalam penyelenggaraan Pemilu di negara demokrasi adalah bahwa penyelenggaraan Pemilu dilaksanakan oleh lembaga yang mandiri dari pemerintah.

Permasalahan yang muncul adalah adanya berbagai macam tindak pidana yang dilakukan yang merebak di berbagai daerah dalam Pemilihan Calon Pemimpin dan sampai sekarang pun terdapat kesulitan untuk mendapatkan bukti-bukti tertulis guna memprosesnya secara hukum. Padahal hukum di Indonesia senantiasa menuntut adanya bukti-bukti tertulis untuk dapat mengajukan seseorang ke pengadilan dengan tuduhan telah melakukan tindak pidana dalam pemilihan kepala daerah.

Banyak kalangan yang meyakini bahwa pemilihan kepala daerah memiliki potensi memicu konflik di masyarakat. Sumber potensi konflik terkait dengan dua hal, pertama berasal dari karakteristik politik lokal dan tingkah laku rata-rata elit atau pemilih yang belum sepenuhnya kondusif bagi sebuah penyelenggaraan pemilihan langsung. Kedua, terdapatnya kelemahan pada beberapa ketentuan didalam peraturan Undang Undang Republik Indonesia Nomor 7 Tahun 2017 tentang Pemilihan Umum. Kelemahan dimaksud terdeteksi pada seluruh siklus Pilkada mulai dari tahap persiapan hingga setelah Pilkada. Dengan kata lain, ketentuan-ketentuan Pilkada belum dapat berfungsi sebagai aturan main guna membatasi tingkah laku 
pemilih, pendukung dan kandidat pilkada. Konsekuensinya, ketentuan perundangundangan berpotensi besar untuk gagal berfungsi sebagai mekanisme penegakan hukum dalam proses Penyelenggaraan Pilkada (Donni Edwin, 2004 : 79).

Dengan perkembangan politik sebagai akibat tuntutan dan kebebasan dalam berdemokrasi, rumusan tindak pidana yang berhubungan dengan tindak pidana politik di dalam KUHP di atas dirasakan sudah tidak dapat menjawab kebutuhan dalam masyarakat. Tindak pidana pemilihan umum (selanjutnya disingkat TPPU) memang memiliki ciri yang khas atau spesifik bila dibandingkan dengan tindak pidana umum.

Berdasarkan uraian di atas, dalam tulisan ini penulis membahas mengenai "bentuk-bentuk tindak pidana dalam Pemilu" didasarkan pada banyaknya tindak pidana yang terjadi dalam masa pemilu dan menjadi bentuk pidana khusus.

\section{PEMBAHASAN}

Pemilu di Indonesia pada hakikatnya merupakan sarana pemenuhan demokrasi dari suatu negara, yakni perwujudan dari asas kedaulatan rakyat sebagaimana rumusan Pasal 1 ayat (2) Undang Undang Dasar Negara Kesatuan Republik Indonesia Tahun 1945. Menurut ketentuan Pasal 1 butir 1 Undang Undang Republik Indonesia Nomor 7 Tahun 2017 tentang Pemilihan Umum adalah sarana kedaulatan rakyat untuk memilih anggota Dewan Perwakilan Rakyat, anggota Dewan Perwakilan Daerah, Presiden dan Wakil Presiden, dan untuk memilih anggota Dewan Perwakilan Rakyat Daerah, yang dilaksanakan secara langsung, umum, bebas, rahasia, jujur, dan adil dalam Negara Kesatuan.

Isu seseorang adalah orang Jawa dan Luar Jawa kerap muncul sebagai isu politik dalam Pilpres. Begitupula dengan isu putra daerah dalam pemilihan jabatanjabatan publik. Penyusunan kekuasaan politik pemerintahan seperti pembentukan Kabinet juga pada faktualnya Presiden dan Wakil Presiden terpilih mau tidak mau harus mempertimbangkan tidak hanya aspek profesionalisme saja, tetapi juga soal representasi wilayah, suku, agama, termasuk perempuan, dan sebagainya. Hal ini membuktikan bahwa politik identitas tetap menjadi pertimbangan dan interpretasinya menjadi sangat beragam dan subjektif, sesuai dengan tendensi politik masing-masing.

Dalam sistem pemilu presiden dan wakil presiden, sistem dilakukan dengan dua cara, yaitu: Pertama, pemilu secara langsung (populary elected) adalah calon 
yang mendapatkan suara terbanyak ditetapkan sebagai presiden terpilih, sedangkan dalam pemilu tidak langsung (electoral college) adalah dilakukan melalui porsi suara wakil rakyat (DPRD Provinsi atau DPRD Kabupaten/ Kota) yang menjadi representasi rakyat dalam pemilihan umum presiden dengan perolehan suara lebih $50 \%$. Calon yang memperoleh suara terbanyak ditetapkan sebagai pemenang dalam pemilu secara langsung, sedangkan dalam pemilu tidak langsung, calon yang menempatkan $50 \%$ wakilnya yang akan terpilih menjadi presiden (Surbakti, dkk., 2011: 9).

Pasal 168 (1) Undang Undang Republik Indonesia Nomor 7 Tahun 2017 tentang Pemilihan Umum menyatakan bahwa Pemilu Presiden dan Wakil Presiden dilaksanakan di seluruh wilayah Negara Kesatuan Republik Indonesia sebagai satu kesatuan daerah pemilihan.

Dalam perspektif kebijakan hukum pidana, sebenarnya perlindungan terhadap berbagai aturan hukum yang bersifat administratif merupakan suatu tuntutan yang wajar, sebab berbagai perilaku yang dilarang oleh ketentuan perundang-undangan administratif baru dapat dikualifikasi sebagai tindak pidana, apabila perbuatan tersebut memenuhi unsur-unsur yang menjadi dasar larangan dari aturan administratif tersebut, sedangkan penggunaan sanksi pidana hanya lebih bersifat menguatkan norma administratif belaka (Muladi, 1990). Walaupun demikian, dalam hal ini tidak boleh dilupakan bahwa penggunaan hukum pidana mempunyai keterbatasan (asas ultimum remedium).

Diakui bahwa pemilu memang bukanlah merupakan wilayah hukum dari hukum pidana, mengingat kaitannya dengan pelaksanaan demokrasi suatu bangsa, oleh sebab itu, pemilu sebenarnya merupakan bagian dari wilayah hukum tata negara, dan karena kebijakan hukum, selanjutnya mekanisme dan penyelenggaraannya dirumuskan di dalam suatu ketentuan perundang undangan, yang melibatkan pula hukum pidana, inklusif sanksi pidana sebagai sanksi penguat norma administratif. Dari perspektif hukum pidana, ada tiga problem dasar yang penting, yakni : (a) ada perbuatan yang dilarang oleh aturan pidana atau tindak pidana; (b) ada orang yang melakukan tindak pidana atau pertanggungjawaban pidana; dan (c) ada sanksi berupa pidana bagi orang yang terbukti bersalah melakukan tindak pidana (Barda Nawawi Arief, 1996).

Pemilu merupakan wujud paling paling nyata sebagai pelaksana demokrasi apakah pihak penyelenggara (Pemerintah, KPU dan Panwaslu) atau pihak peserta 
pemilihan umum (rakyat dan para calon) yang selalu melakukan pelanggaran. Oleh karena itu, semua pelanggaran pemilu harus ditindak, dan perbuatan yang bermaksud membuat pemilihan umum itu menjadi tidak demokratis yaitu, tidak jujur dan tidak adil (Jurdil). Upaya awal untuk mencegah tindakan-tindakan yang tidak demokratis terhadap pelaksanaan pemilu, pemerintah merujuk kepada Kitab Undang-Undang Hukum Pidana (KUHP) Buku II Bab IV tentang Kejahatan terhadap pelaksanaan kewajiban dan hak kenegaraan.

Sesuai Pasal 22E ayat (6) UUD Tahun 1945, pemilihan umum adalah untuk memilih anggota Dewan Perwakilan Rakyat, Dewan Perwakilan Daerah, dan Dewan Perwakilan Rakyat Daerah diselenggarakan berlandaskan azas langsung, umum, bebas, rahasia, jujur, dan adil setiap lima tahun sekali.

Pemilihan umum dimaksud, diselenggarakan dengan menjamin prinsip keterwakilan, artinya setiap warga negara Indonesia terjamin memiliki wakil yang duduk di lembaga perwakilan yang akan menyuarakan aspirasinya pada setiap tingkatan pemerintahan dari pusat hingga ke daerah dan yang menarik adalah bahwa ternyata pelaksanaan pemilu bukanlah hal yang mudah. Prinsip penyelenggaraan pemilu sesuai asas langsung, dimaksudkan agar rakyat sebagai pemilih mempunyai hak untuk memberikan suaranya secara langsung sesuai kehendak hati nuraninya, tanpa perantara. Demikian juga yang bersifat umum, mengandung makna menjamin kesempatan yang berlaku menyeluruh bagi semua warga negara, tanpa diskriminasi berdasarkan suku, agama, ras, golongan, jenis kelamin, kedaerahan, pekerjaan, dan status sosial.

Setiap warga negara yang berhak memilih bebas menentukan pilihannya tanpa tekanan dan paksaan dari siapa pun. Dalam melaksanakan haknya, setiap warga negara dijamin keamanannya oleh negara, sehingga dapat memilih sesuai dengan kehendak hati nurani. Dalam memberikan suaranya, pemilih dijamin bahwa pilihannya tidak akan diketahui oleh pihak mana pun. Pemilih memberikan suaranya pada surat suara dengan tidak dapat diketahui oleh orang lain. Dalam penyelenggaraan pemilu ini, penyelenggara pemilu, aparat pemerintah, peserta pemilu, pengawas pemilu, pemantau pemilu, pemilih, serta semua pihak yang terkait harus bersikap dan bertindak jujur sesuai dengan peraturan perundang-undangan. Setiap pemilih dan peserta pemilu mendapat perlakuan yang sama, serta bebas dari kecurangan pihak manapun. 
Dalam prakteknya, keinginan sebagaimana di atas tidak selamanya dapat dipenuhi, sebab kecenderungan memanfaatkan kesempatan untuk memenangkan salah satu pihak atau juga partai peserta pemilu senantiasa terbuka. Oleh sebab itu, seringkali tidak dapat dihindari adanya perilaku menyimpang yang cenderung melanggar norma. Dengan berkembangnya masyarakat yang diiringi dengan terbatasnya lapangan kerja, maka tidak dapat disangkal bahwa keadaan demikian akan cenderung berpeluang menimbulkan berbagai jenis kejahatan, yang dampaknya bukan saja pada gangguan dan kerugian bagi individu dan masyarakat, tetapi juga bangsa. Seringkali jika timbul gangguan dan kerugian orang cenderung berpaling pada hukum pidana, dan berharap penegakan hukum pidana akan mampu menanggulangi fenomena kejahatan tersebut, sehingga terciptanya kedamaian dan ketentraman.

Dengan diaturnya masalah tindak pidana dalam pemilihan umum, baik dalam KUHP maupun Undang-undang Pemilihan Umum termasuk juga aturan KPU, ini menunjukan kepada kita bahwa pembuat undang-undang menganggap pemilihan umum itu merupakan hal yang sangat penting dalam kehidupan demokrasi dan bernegara di Indonesia dan yang sangat penting adalah bila pemilihan umum tersebut bisa dilaksanakan dengan Jujur dan adil. Mengingat pentingnya posisi pemilihan umum bagi sebuah negara yang demokrasi, maka adalah tidak berlebihan bila dikatakan kebersihan, kejujuran dan keadilan dalam pelaksanaan pemilihan umum akan mencerminkan kualitas demokrasi di negara bersangkutan.

Kemampuan menampakan atau mewujudkan pemilihan umum yang jujur dan adil akan berarti pula melihatkan kematangan masyarakat selaku peserta pemilihan umum dalam berdemokrasi. Secara konseptual dan empirik, demokrasi akan tumbuh dan berkembang secara optimal manakala didukung oleh peradaban masyarakat negara setempat yang membuka ruang terbentuknya proses demokrasi. Peradaban masyarakat dapat bersumber dari bawaan manusia hasil interaksi dengan lingkungan, juga merupakan hasil pelaksanaan program modernisasi yang dilakukan oleh pemerintah dalam berbagai aspek kehidupan melalui pembentukan perangkat aturan tentang pelaksanaan demokrasi.

Perlu dilakukan terobosan mengenai penggunaan hukum pidana itu sebagai sarana (tool) untuk menanggulangi kejahatan dan berbagai gangguan sosial secara arif dan bijaksana. Pandangan ini beralasan mengingat dari perspektif kriminologis, penyebab kejahatan itu sendiri tidak semata-mata bersumber dari keadaan diri 
seseorang, akan tetapi juga merupakan akibat dari keadaan lingkungan di mana ia berada (anomie) yang didukung oleh kemajuan iptek. Karena itu tidak dapat dipungkiri bahwa permasalahan kejahatan memang senantiasa bersifat mutlidimensi. (Romli Atmasasmita, 1982)

Terhadap hal demikian, dari perspektif kebijakan hukum pidana yang perlu menjadi kajian adalah, bagaimana membenahi perangkat sistem hukum pidana Indonesia saat ini, yang antara lain meliputi :

(a) pengaturan terhadap substansi hukum pidana materiil;

(b) pengaturan terhadap struktur kelembagaan hukum pidana yang profesional; serta;

(c) pengaturan terhadap sistem pidana dan pemidanaan yang manusiawi. (Muladi, 1990)

Kebijakan hukum pidana (penal policy) atau dikenal dengan istilah politik hukum pidana memang merupakan salah satu pendekatan dalam hukum pidana modern (the modern ciminal science), selain pendekatan "criminology" dan "criminal law" (Marc Ancel, 1965 : 4-5). Menurut Ancel, kebijakan hukum pidana merupakan suatu ilmu sekaligus seni yang pada akhirnya mempunyai tujuan praktis untuk memungkinkan peraturan hukum positif dirumuskan secara lebih baik, dan memberi pedoman tidak hanya kepada pembuat undang-undang, tetapi juga kepada pengadilan yang menerapkan undang-undang dan juga kepada para penyelenggara atau pelaksana putusan pengadilan. Dikatakan, "di antara studi mengenai faktorfaktor kriminologis di satu pihak, dan studi mengenai teknik perundang-undangan di lain pihak, ada tempat bagi suatu ilmu pengetahuan yang mengamati dan menyelidik fenomena legislatif yang rasional, di mana para sarjana dan praktisi, para ahli kriminologi dan sarjana hukum dapat bekerjasama, tidak sebagai pihak yang saling berlawanan atau berselisih, tetapi sebagai kawan sekerja yang terikat di dalam tugas bersama, yaitu terutama untuk menghasilkan suatu kebijakan pidana yang realistik, humanis dan berpikiran maju (progresif) lagi sehat.

Istilah "kebijakan" berasal dari istilah "policy" (Inggris) atau "politie" (Belanda). Menurut Robert R Mayer dan Ernest Greenwood "kebijakan" (policy) dapat dirumuskan sebagai suatu keputusan yang menggariskan cara yang paling efektif dan efisien untuk mencapai suatu tujuan yang ditetapkan secara kolektif. Menurut Sudarto (1981: 15) politik hukum adalah : 
1. Usaha untuk mewujudkan peraturan-peraturan yang baik sesuai dengan keadaan dan situasi pada suatu saat;

2. Kebijakan dari negara melalui badan-badan yang berwenang untuk menetapkan peraturan-peraturan yang dikehendaki yang diperkirakan bisa digunakan untuk mengekspresikan apa yang terkandung dalam mayarakat dan untuk mencapai apa yang dicita-citakan. (Sudarto, $1983: 20$ )

Memahami pengertian kebijakan hukum pidana atau "penal policy" di atas, diasumsikan bahwa usaha dan kebijakan untuk membuat peraturan hukum pidana yang baik pada hakekatnya tidak dapat dilepaskan dari tujuan penanggulangan kejahatan. Kebijakan atau politik hukum pidana juga merupakan bagian dari politik kriminal. Dilihat dari persepktif politik kriminal, politik hukum pidana identik dengan pengertian kebijakan penanggulangan kejahatan dengan menggunakan sarana hukum pidana (penal). Dalam konteks yang lebih besar, kebijakan hukum pidana juga merupakan bagian dari usaha penegakan hukum (pidana). Karena itu kebijakan hukum pidana merupakan bagian dari kebijakan penegakan hukum (Law enforcement policy). Apabila tujuan hukum pidana adalah melindungi kepentingan negara dan masyarakat, maka pemilu sebagai bagian dari usaha demokratisasi suatu negara, termasuk Indonesia juga mesti mendapat perlindungan. Hal ini dimaksudkan bahwa negara bermaksud mengatur ketertiban umum di dalam negara tersebut.

Muladi (1990: 7) dalam kaitan itu menegaskan bahwa keterlibatan hukum pidana ke dalam bidang hukum lainnya (administratif) hanya bersifat komplementer. Dalam hal semacam ini, kedudukan hukum pidana hanya bersifat menunjang penegakan norma yang ada di bidang hukum lainnya, seperti perpajakan, hak cipta, paten dan sebagainya. Bahkan dalam hal tertentu perannya diharapkan lebih bersifat fungsional, daripada sekedar bersifat subsider, mengingat situasi perekonomian (politik dalam negeri) yang kurang menguntungkan. Dalam pada itu, maka diakuinya bahwa fungsionalisasi hukum pidana atau tegasnya sanksi pidana dalam hal ini merupakan tuntutan yang wajar, mengingat kepentingan hukum yang dilindungi sangat besar.

Pemilu merupakan salah satu benda hukum yang dilindungi hukum pidana. Alasannya, hukum pidana memang memiliki kelebihan dibandingkan dengan bidang hukum lainnya. Sebagai hokum, sanksi yang negatif, inklusif sanksi pidana dapat digunakan sebagai sarana (tool) karena memiliki daya pemaksa agar orang menjadi 
patuh pada aturan. Menurut Barda Nawawi Arief (2005), pada hakekatnya hukum pidana berfungsi melindungi berbagai kepentingan tertentu, dan karena itu menurutnya kepentingan tersebut bisa individu, masyarakat, bangsa dan negara.

Pemilihan umum sebagai salah satu sarana demokrasi rakyat baru beberapa kali diselenggarakan di Indonesia, bahkan pada tahun-tahun terakhir ini akibat perubahan paradigma peta politik dunia dan tuntutan demokratisasi masing-masing negara, membuat pemerintah dan kalangan politisi senantiasa mencari format yang tepat mengenai bagaimana pemilu diselenggarakan. Hal ini wajar, sebab sebagai bangsa yang berbudaya, kita pun tidak ingin terjebak pada kepentingan-kepentingan sesaat berdasarkan ideologi sempit, yang tidak sejalan dengan ideologi Pancasila yang merupakan komitmen bangsa sejak kemerdekaan Indonesia tahun 1945. Walaupun demikian, diakui juga bahwa apapun baik dan sempurnanya suatu sistem demokrasi, namun kita mesti pula kembali pada etika dan budaya bangsa. Undangundang pemilu memang telah dibuat, dan mengalami beberapa kali perubahan, namun tidak dapat disangkal bahwa ternyata masih saja ada kecenderungan dalam bentuk pelanggaran-pelanggaran yang memiliki dimensi hukum penting ini.

Menyelusuri beberapa rumusan tindak pidana tentang pemilihan umum selama ini di dalam beberapa peraturan perundang undangan di Indonesia, terdapat beberapa rumusan tindak pidana sebagaimana diatur dalam Bab IV Buku II KUHP, seperti ditemui dirumuskan dalam :

1. Pasal 148, yang memidana seseorang apabila dengan sengaja dan dengan kekerasan atau dengan ancaman kekerasan merintangi seseorang yang akan melakukan hak memilihnya menjadi terganggu.

2. Pasal 149 yang pada waktu pemilihan umum berlangsung memberikan atau menjanjikan atau menyuap seseorang agar tidak menggunakan hak pilinnya, atau mengikuti apa yang diiginkan pemberi, bahkan terhadap penerima suab juga dapat dikenakan pidana.

3. Pasal 150, yakni perbuatan tipu muslihat yang menyebabkan suara seorang pemilih menjadi tidak berharga.

4. Pasal 151 yang merumuskan perbuatan dengan sengaja mengaku dirinya orang lain, dan

5. Pasal 152 merumusakan perbuatan dengan sengaja menggagalkan pemungutan suara yang telah dilakukan atau melakukan perbuatan tipu muslihat yang menyebabkan hasil pemungutan menjadi lain. 
Menyimak rumusan perbuatan pidana dan pola perumusan ancaman pidana di dalam Pasal-Pasal KUHP di atas, dikatakan bahwa rumusannya memang masih sangat sederhana, karena itu rata-rata ancaman sanksi pidana berkisar antara 9 (sembilan) bulan hingga 2 (dua) tahun pidana penjara, dan tidak dikenakan sanksi pidana denda. Ini tentu merupakan bentuk kebijakan perumusan masa lalu yang cenderung bersifat kolonial, karena diakui bahwa KUHP yang saat ini berlaku bagi bangsa Indonesia merupakan warisan kolonial sejak jaman Hindia Belanda.

Dengan perkembangan politik sebagai akibat tuntutan dan kebebasan dalam berdemokrasi, rumusan tindak pidana yang berhubungan dengan tindak pidana politik di dalam KUHP di atas dirasakan sudah tidak dapat menjawab kebutuhan dalam masyarakat. Tindak pidana pemilihan umum memang memiliki ciri yang khas atau spesifik bila dibandingkan dengan tindak pidana umum, sebab Tindak Pidana Pemilihan Umum (selanjutnya disingkat TPPU) hanya mungkin terjadi dalam pemilihan umum (dalam tahapan dari proses dan pemungutan suara) karena pemilihan umum di Indonesia dilangsungkan sekali dalam 5 tahun. Maka terjadinya TPPU itu pun hanya dalam kurun waktu tersebut. Sedangkan tindak pidana lain, seperti pencurian, pembunuhan dan korupsi dan lain-lain bisa terjadi setiap waktu. Sebagai konsekuensi dari kondisi dan waktu terjadinya TPPU, maka masyarakat dan aparatur negara (Pemerintah, Kepolisian, Kejaksaan dan Panwaslu) banyak yang tidak mengetahui, lupa atau kurang memahami apa dan bagaimana ketentuan dari TPPU.

Ketika ada yang melanggar tindak pidana pemilihan umum, ini banyak orang yang tidak sadar bahwa Pemilu dan Demokrasi telah ternoda. Kondisi demikian didukung pula oleh adanya asumsi bahwa pemilihan umum memiliki nilai sensitivitas yang tinggi, sesuatu yang peka atau tabu untuk dipersoalkan, sehingga semakin tenggelam tentang perbuatan melanggar hukum (onrechtmatigheid) dalam pemilihan umum. Sedangkan perbuatan TPPU yang menodai pemilu dan demokrasi itu adalah kejahatan atau pelanggaran yang oleh peraturan diancam dengan hukuman yang tidak ringan.

Bentuk-bentuk Tindak Pidana Pemilihan Umum sebagaimana yang dimaksud Pasal 1 ayat (1) Undang-Undang Nomor 7 tahun 2017 tentang Pemilihan Umum yang berasas LUBER di dalam Negara Kesatuan Republik Indonesia berdasarkan Pancasila Undang-Undang Dasar Negara Republik Indonesia Tahun 1945". Dan pemilihan umum dilaksanakan satu kali dalam masanya 5 (lima) tahun, ini sesuai 
dengan Pasal 22E ayat (1) UndangUndang Dasar 1945 berbunyi, "Pemilihan umum dilaksanakan secara langsung, umum, bebas, rahasia, jujur, dan adil setiap lima tahun sekali". Sudah tentu bahwa tindak pidana pemilihan umum itu hanya terjadi dalam kurung waktu tersebut, akan tetapi pelanggaran terhadap tindak pidana pemilihan umum yang terjadi 5 (lima) tahun sekali ini perlu di tindak terhadap pelanggarannya. Meskipun dilakukan 5 (lima) tahun sekali pemilu itu adalah hal yang hakiki atau penting dalam suatu negara yang demokrasi dan Pemilu itu tidak boleh cacat dan ternoda dalam pelaksanaannya. Perbuatan tindak pidana Pemilu sebelum terbitnya Undang-Undang Pemilu sudah diatur dalam Kitab Undang-Undang Hukum Pidana (KUHP) yaitu Pasal 148, Pasal 149 ayat (1) dan ayat (2), Pasal 150, Pasal 151 dan Pasal 152 Kitab UndangUndang Hukum Pidana (KUHP). Disamping TPPU yang diatur dalam KUHP juga diatur lebih rinci dan tegas terhadap tindak pidana pemilu dalam Undang-Undang Republik Indonesia Nomor 1 Tahun 2017 tentang Pemilihan Umum

Menurut Barda Nawawi Arief (2005 : 29) di dalam kebijakan hukum pidana, terdapat 2 (dua) masalah sentral yang mesti menjadi perhatian jika hukum pidana, inklusif sanksi pidana ingin dilibatkan yakni :

1. Perbuatan apa yang seharusnya dijadikan tindak pidana; dan

2. Sanksi apa yang sebaiknya digunakan atau dikenakan kepada si pelanggar.

Ditegaskan oleh Barda Nawawi Arief, analisa terhadap masalah sentral ini tidak dapat dipisahkan dari konsepsi integral kebijakan kriminal dengan kebijakan sosial dan kebijakan pembangunan nasional. Artinya, pemecahan masalah-masalah di atas harus pula diserahkan untuk mencapai tujuan-tujuan tertentu dari kebijakan sosial yang telah ditetapkan. Dengan demikian, kebijakan hukum pidana termasuk pula kebijakan dalam menangani dua masalah sentral di atas, harus pula dilakukan dengan pendekatan yang berorientasi pada kebijakan (policy oriented approach).

Relevan dengan pendapat Barda Nawawi, Sudarto (1977: 44 - 48) berpendapat bahwa dalam menghadapi dua masalah sentral di atas, maka terhadap masalah sentral yang pertama harus diperhatikan hal-hal yang pada intinya :

1. Penggunaan hukum pidana harus memperhatikan tujuan pembangunan nasional, yaitu perwujudan masyarakat adil dan makmur yang merata baik materiil dan spirituil berdasarkan Pancasila; sehubungan dengan ini maka (penggunaan) hukum pidana bertujuan untuk menanggulangi kejahatan dan mengadakan 
penggugeran terhadap tindakan penganggulangan itu sendiri, demi kesejahteraan dan pengayoman masyarakat;

2. Perbuatan yang diusahakan untuk dicegah atau ditanggulangi dengan hukum pidana harus merupakan perbuatan yang tidak dikehendaki, yaitu perbuatan yang mendatangkan kerugian (materiil dan sipirutil) atas warga masyarakat;

3. Penggunaan hukum pidana harus pula memperhitungkan prinsip biaya dan hasil (cost and benefit principle);

4. Penggunaan hukum pidana harus pula memperhatikan kapasitas atau kemampuan daya kerja dari badan badan penegak hukum, yaitu jangan sampai ada kelampauan beban tugas (overbelasting).

Sama halnya dengan masalah pemilu, bahwa penyelenggarannya tidak berdiri sendiri atau bersifat fakultatif, akan tetapi merupakan bagian dari politik sosial suatu bangsa, dan karena itu diperlukan adanya pengamanan melalui kebijakan hukum atau politik hukum, yang dalam hal ini dapat berupa penggunaan sarana hukum administrasi maupun sarana hukum pidana (penal).

Dalam arti penggunaan hukum administrasi, maka rumusan perbuatan yang berkaitan dengan penyelenggaraan pemilu lebih digantungkan pada asas dan norma yang berlaku di dalam hukum administrasi itu sendiri, karena itu "inti rumusan perilaku dan/atau perbuatan" yang dianut di dalam undang undang pemilu disebut dalam beberapa kategori, yakni peserta, pelaksana, penyelenggara, lembaga pemerintah dan peradilan, maupun masyarakat dalam proses pemilihan umum mesti lebih bersifat teknis administratif. Jika di antara pelaku, pelaksana, penyelenggara, lembaga pemerintah maupun masyarakat pada umumnya ada yang melanggar, maka sebaiknya digunakan terlebih dahulu sanksi yang besifat administratif, dan apabila usaha penggunaan sanksi tersebut tidak mendapat dukungan, barulah digunakan sanksi hukum pidana. (asas ultimum remedium atau subsider).

Hal ini mesti dipahami secara benar, sebab penggunaan sarana hukum pidana, inklusif sanksi pidana di dalam menanggulangi berbagai pelanggaran baik sebelum, selama maupun setelah pemilu dilaksanakan tidak selalu efektif. Hal ini terlihat dalam beberapa kasus yang pada suatu daerah diperiksa dan diberi sanksi oleh lembaga pengadilan, namun pada beberapa daerah lainnya tidak demikian.

Menurut Bassiouni (1978 : 82-84) bahwa seharusnya dipertimbangkan sebagai salah satu scientific device dan digunakan sebagai alternatif dari 
pendekatan dengan penilaian emosional (the emosionally laden value judgment approach) oleh kebanyakan badan-badan peradilan.

Menurut Bassiouni, perkembangan 'a policy oriented approach' ini lamban datangnya, karena proses legislatif belum siap untuk pendekatan yang demikian. Proses kriminalisasi yang berlangsung terus tanpa suatu evaluasi mengenai pengaruhnya terhadap keseluruhan sistem mengakibatkan timbulnya :

1. Krisis kelebihan kriminalisasi (the crisis of over criminalization) dan;

2. Krisis kelampauan batas dari hukum pidana (the crisis of overreach of the criminal law)

\section{Kesimpulan}

1. Pemilihan umum merupakan perintah dari Undang-Undang Dasar 1945 untuk melaksanakan asas kedaulatan rakyat yang dilaksanakan lima tahun sekali di Negara Republik Indonesia dengan tujuan:

a. Menyusun Lembaga Permusyawaratan Rakyat yang dijiwai semangat Pancasila dan UndangUndang Dasar Republik Indonesia Tahun 1945.

b. Memilih wakil-wakil rakyat dan Presiden dan Wakil Presiden dalam melanjutkan perjuangan mempertahankan dan mengembangkan tujuan dari negara.

c. Pemilihan umum adalah suatu alat melaksanakan demokrasi untuk menegakan tegaknya Pancasila dan mempertahankan UndangUndang Dasar Republik Indonesia 1945.

d. Untuk menjamin kesinambungan pemerintah lima tahun dan mengisi pembangunan nasional.

2. Tindak Pidana Pemilu dapat dimasukkan dalam pidana khusus yaitu pidana pemilu dan pelanggaran baik diatur dalam Kitab Undang-Undang Hukum Pidana (KUHP) dan diatur dalam Undang-Undang Nomor 7 Tahun 2017 tentang Pemilihan Umum. Adapun para pihak yang dapat disangkakan terhadap tidak pemilu adalah:

a. Penyelengara Pemilu (KPU, Bawaslu, Pemerintah).

b. Peserta Pemilihan Umum (Partai Politik, Calon DPR, DPD, DPRD, Calon Presiden dan Wakil Presiden). 
c. Masyarakat sebagai subjek hukum (sebagai pemilih, Tim Sukses termasuk Masyarakat yang mengajak tidak menggunakan hak suaranya).

3. Fenomena pelanggaran sebelum, selama dan setelah penyelenggaraan pemilu berlangsung, diakui bahwa banyak sekali pelanggaran yang diproses dengan aturan undang undang pemilu, yang tidak memberikan manfaat dilihat dari kepentingan hukum pidana. Hal ini beralasan, karena dalam konteks penegakan hukum pidana, "spirit of law" yang mendasari pembentukan undang-undang pemilu.mesti menjadi alasan kenapa perbuatan yang dilanggar itu mesti ditegakan.

4. Adanya syarat yang perlu diperhatikan dalam proses penegakan hukum, khususnya dalam kasus pemilu, yakni adanya keseimbangan, keselarasan dan keserasian antara "kesadaran hukum" yang ditanamkan oleh penguasa (legal awarness) dengan perasaan hukum yang spontan dari rakyat (legal feeling).

5. Bahwa konsep penegakan hukum tidak terlepas dari perkembangan demokrasi dan politik, di mana dalam masyarakat yang besar dan pluralistik, pelaksanaan demokrasi sangat dipengaruhi oleh kebijakan publik yang banyak ditentukan oleh pemimpin-pemimpin (elites) organisasi politik dan kelompok kepentingan (interst groups) yang tampil secara kompetetif. Pada hal mereka justru diharapkan selalu memegang komitmen terhadap nilainilai dasar masyarakat. 


\section{DAFTAR PUSTAKA}

Donni Edwin, Pilkada Langsung Demokratisasi Daerah dan Mitos Good Governance, Partnership dan Pusat Kajian IImu Politik, Jakarta, 2004.

Gaffar Jenedjri M, Demokrasi dan Pemilu di Indonesia, Konpres, Jakarta, 2013,

---------, Demokrasi Lokal Pemilukada di Indonesia, Konpres, Jakarta, 2012,

Muladi, Kapita Selekta Sistem Peradilan Pidana, Badan Penerbit UNDIP, Semarang, 1995.

Mulyadi, Dedi, Kebijakan Legislasi tentang Sanksi Pidana Pemilu Legislatif Di Indonesia dalam Perspektif Indonesia, Gramata Publishing, Jakarta, 2012 ,

Sugandhi, R., Kitab Undang-Undang Hukum Pidana Dengan Penjelasannya, Usaha Nasional, Surabaya, 1981.

Sardini, Nur Hidayat, Menuju Pengawasan Pemilu Efektif, Diadit Media, Jakarta, 2013,

---------, Restorasi Penyelenggara Pemilu di Indonesia, Fajar Media Press, Yogyakarta, 2011.

Sarundajang, Pilkada Langsung, Problema dan Prospek, Kata Hasta Pustaka, Surabaya, 2005.

Sintong Silaban, Tindak Pidana Pemilu (suatu tinjauan dalam rangka mewujudkan pelaksanaan pemilu yang jujur dan adil), Pustaka Sinar Harapan, Jakarta, 1992.

Sudarto, Hukum Pidana I, Yayasan Sudarto, Semarang, 1990.

---------, Kapita Selekta Hukum Pidana, Alumni, Bandung, 1981.

Sumiarmi, Politik Hukum \& Tata Hukum Indonesia, Cahaya Atma Pustaka, (cetakan kelima), Yogyakarta, 2015.

Utrecht, Hukum Pidana I, Universitas Padjajaran, Bandung, 1968.

Kitab Undang-Undang Hukum Pidana (KUHP)

Undang-Undang Nomor 7 Tahun 2017 Tentang Pemilihan Umum. 